\title{
Treatment of Poultry Slaughterhouse Wastewater Using an Expanded Granular Sludge Bed Reactor Coupled with a Membrane Bioreactor and UV Systems
}

\author{
Honeil B. Meyo ${ }^{a, b}$, Moses Basitere ${ }^{a, b}$, Seteno K. O. Ntwampe ${ }^{a, b}$ and Cebisa T. Mdladla ${ }^{a}$
}

\begin{abstract}
Poultry slaughterhouses consume a high quantity of potable water and in turn generate large quantities of high strength wastewaters. The PSW can be treated effectively at minimal cost using anaerobic treatment process. This paper is a review on the possibility of using an expanded granular sludge bed reactor (EGSB) coupled with a membrane bioreactor (MBR) and an ultraviolet (UV) system to treat poultry slaughterhouse wastewater (PSW). A brief overview of wastewater, the composition and the characteristics of PSW are given. In this review paper, the pre-treatment techniques of treatment of PSW will be discussed with a focus on physical process such as screeners for solid removal, biological pre-treatment reactors, EGSB reactor. The MBR will consist of simultaneous nitrification-denitrification (SND), UF submerged Membrane and the product will pass through the UV systems for pathogens removal.
\end{abstract}

Keywords-Expanded Granular Sludge Bed reactor (EGSB), Membrane Bioreactor (MBR), Poultry Slaughterhouse Wastewater (PSW), Ultraviolet (UV) systems.

\section{INTRODUCTION}

A typical challenge confronting the poultry industry all over the world is the drinking of a high amount of clean water for the way toward cleaning of their facilities, and removing feathers of butchered chickens [1], [2]. This utilization of enormous amounts of consumable water at that point delivers huge volumes of wastewater, which contain elevated concentrations of carbon-based (organic) matter, nutrients (nitrogen \& phosphorus) [1], [2]. This wastewater produced is at any rate fundamentally more polluted than local sewage wastewater, which will result in elevated biological and chemical oxygen demand than local sewage [2], [3].

Manuscript received October 10, 2019. This work was supported in part by CPUT under URF RK16 and BIOERG under RK45.

a Cape Peninsula University of Technology, Department of Chemical Engineering, P.O. Box 1906, Bellville 7535, South Africa.

${ }^{\mathrm{b}}$ Bioresource Engineering Research Group (BioERG), Department of

Biotechnology, Cape Peninsula University of Technology, P.O. Box 652, Cape Town 8000, South Africa.
Regardless of the way that the poultry industry is an enormous user of clean water and subsequently produces a huge amount of high wastewater, negligible consideration has been set to the control of the effluent [4], principally in Cape Town (CPT). Quick transfer of such effluent into nature levitates a worry as it brings about the spread of diseases, coming full circle in the contamination of nearby waterways [5]. Hence the treatment of this wastewater for re-utilization is essential to decrease the unsustainable use of consumable water [5].

Wastewater treatment methods utilized by poultry slaughterhouses mostly comprise of the initial stage which is screening to segregate solids and colossal particles from the fluid segment in poultry slaughterhouse wastewater (PSW) and oust up to $30 \%$ of the $\mathrm{BOD}_{5}$ [6]. Notwithstanding these treatment forms, a few different procedures have been accounted for PSW treatment, with high-rate anaerobic procedures being the most regularly utilized because of their high generally treatment performance and reasonableness for the treatment of discharge with high carbon-based load [7], [8]. The expanded granular sludge bed (EGSB) digester work at long HRT and short SRT which encourages the treatment of a huge amount of wastewater utilizing exceptionally dynamic biomass [9]. The EGSB was created to disentangle the structure, activity, and support of high-rate anaerobic reactors while as yet keeping up high calibre influent treatment [9]. The structure of the EGSB is an enhancement of the UASB reactor plan [9], [10]. The EGSB has demonstrated does effectiveness for treating the diverse quality of wastewaters comprise PSW [9], [11].

Due to progressively stringent ecological guidelines with respect to high nitrogen \& phosphorous levels just as developing enthusiasm for the re-utilization of water\& recovery, SND, which consolidates heterotrophic nitrification and aerobic denitrification forms, can be considered as an alluring after treatment for anaerobic discharges [8], [9]. Moreover, MBR has demonstrated to be productive in the evacuation of macronutrients from PSW and others (textile wastewater, soft drink wastewater) [2], [11]- [13]. In addition, UV lights also have demonstrated to be efficient in terms of pathogens removal from sewage-treated effluent and biosolids for agricultural reasons [14]- [16]. 


\section{POULTRY SLAughterhouse WASTEWATER}

\section{A. Wastewater}

The term wastewater translates to "utilized water", and is generated from the industrial processes that require moderate or extensive potable water (textile, domestic, municipal, industrial, agricultural and so on.) and it is comprised of $99.90 \% \mathrm{H}_{2} \mathrm{O}$ and $0.10 \%$ solids[18], [19]. Wastewater can be qualified as untreated when its concentration of contaminants hasn't been reduced to discharge standards [20]. The major contaminants of poultry slaughterhouse wastewater are suspended solids. These should be removed prior to the discharge of wastewater to prevent the pollution of the environment because they consist of organic matter that can be characterized in terms of chemical oxygen demand (COD), total suspended solids (TSS) or Biological oxygen demand $\left(\mathrm{BOD}_{5}\right)$. Depending on the concentration of contaminants in the wastewater, the latter can be identified by foul smells [19]. These odors result from the bioprocessing of microscopic organisms which is associated with the release of some gases, such as $\mathrm{H}_{2} \mathrm{~S}$, which promotes such odors. These microscopic organisms prevail under mild to moderate temperatures and are inactive under high and low temperature $(>4)$, microbial development multiplication is predominant. Furthermore, wastewater additionally contains organic matter [suspended solids, protein and fats, oil \& grease (FOG)] which add to elevated concentrations of BOD and COD. Further components incorporate nutrients and inorganics (nitrogen and phosphorous mixes) which are the fundamental sources of eutrophication, a phenomenon that seriously affects water bodies due to the oversupply of nutrients and organic matter [21]. Various industries generate industrial wastewater, subsequently its features vary from one to another industry.

\section{B. The Composition of Poultry Slaughterhouse Wastewater}

In wastewater treatment industries, the most critical part is the decrease of ecological contamination. To avoid financial penalties associated with levies from the discharge of untreated wastewater, poultry slaughterhouses are required to treat their wastewater prior to discharge. This incentive is geared towards protecting the aquatic fauna and the flora surrounding poultry slaughterhouses, as poultry slaughterhouse wastewater (PSW) has been reported to present characteristics that surpass the discharge standards limits [22]. Poultry slaughterhouse wastewater contributes immensely to ecological contamination issues; it endangers humans, creatures and amphibian life on the off chance that it is released untreated into clean water streams [23]. PSW is composed of organic matters quantifiable by wastewater assessment parameters such as TSS, COD, BOD ; nutrients; fats, oil and grease (FOG); and traces of inorganic matters[3], [24], [25].

Most of the microorganisms are also found in wastewater and are pathogenic. Microscopic organisms that endure the cleaning of gears and surface territories are viewed as impervious to the anti-microbial products utilized, which ends inside the wastewater[4]. The average concentration of $\mathrm{BOD}_{5}$ and $\mathrm{COD}$ in PSW is extensively higher than those detected from household anthropogenic doings [26].

\section{The Characteristics of Poultry Slaughterhouse Wastewater}

The PSW is composed of stems from the excrement, pee, blood, built up, fat, carcass, and non-processed nourishment in the digestive organs of the slaughtered chickens/birds and the cleaning of the slaughterhouse facilities. The composition of the abattoir wastewater differs as per the water used and industrial process [27]. The PSW generated from the poultry industry globally represents an environmental concern because of the slaughterhouse wastewater complex creation of proteins, filaments, fats oil\& grease (FOG), high strength organic matter content, and pathogens[6], [27]. Slaughterhouse waste is normally assessed utilizing mass parameters due to the wide scope of slaughterhouse wastewater and contaminant loads. Slaughterhouse wastewater contains high quantities of biochemical oxygen demand (BOD), chemical oxygen demand (COD), total organic carbon (TOC), total nitrogen (TN), total phosphorus (TP), and total suspended solids (TSS)[6]. Distinctive features of an untreated poultry slaughterhouse wastewater in South Africa (SA) is listed in Table I.

TABLE I: Distinctive FEATURES OF AN UNTREATED POULTRY SLAUGHTERHOUSE WASTEWATER (NON-FILTERED) IN CAPE TOWN [28].

\begin{tabular}{llll}
\hline \hline Parameter & Unit & \multicolumn{2}{c}{ PSW } \\
\hline & & Range & Average \\
$\mathrm{pH}$ & - & $6.1-7.2$ & - \\
TDS & $\mathrm{Ppm}$ & $691-1,693$ & 1,138 \\
Conductivity & $\mu \mathrm{S} / \mathrm{cm}$ & $973-2,403$ & 1,604 \\
Turbidity & $\mathrm{NTU}$ & $237-997$ & 719 \\
Salinity & $\mathrm{Ppm}$ & $529-1,413$ & 916 \\
TSS & $\mathrm{mg} / \mathrm{L}$ & $313-8,200$ & 1,654 \\
VSS & $\mathrm{mg} / \mathrm{L}$ & $239-8,920$ & 1,906 \\
$\mathrm{COD}$ & $\mathrm{mg} / \mathrm{L}$ & $2,517-12,490$ & 5,216 \\
$\mathrm{NH}_{4}{ }^{+}-\mathrm{N}$ & $\mathrm{mg} / \mathrm{L}$ & $135-447$ & 216 \\
$\mathrm{NO}_{3}{ }^{-} \mathrm{N}$ & $\mathrm{mg} / \mathrm{L}$ & $0.63-22.7$ & 3,33 \\
$\mathrm{PO}_{4}{ }^{3-} \mathrm{P}$ & $\mathrm{mg} / \mathrm{L}$ & $29-54$ & 38 \\
$\mathrm{VFA}^{\mathrm{Alkalinity}}$ & $\mathrm{mg} / \mathrm{L}$ & $105-898$ & 375 \\
FOG & $\mathrm{mg} / \mathrm{L}$ & $322-923$ & 499 \\
BOD & $\mathrm{mg} / \mathrm{L}$ & $156-1,710$ & 715 \\
\hline \hline
\end{tabular}

\section{MATERIALS AND SySTEM DESIGN}

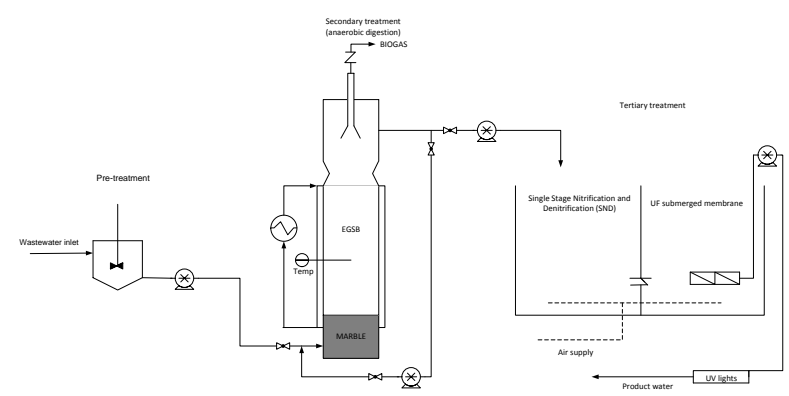

Fig. 1. Magnetization as a function of applied field Poultry Slaughterhouse Wastewater treatment plant (lab scale) Adopted from Kaskote [43]

The PSW treatment plant consists of a pre-treatment stage, an EGSB reactor, an SND, UF submerged membrane and UV lights.

The pre-treatment stage is added to minimize solid concentration, reduce FOG and $\mathrm{BOD}_{5}$ in the PSW thus resulting in more efficient EGSB operation with reduction of clogging. The biological treatment of removing total nitrogen in the 
wastewater by SND is used because of its cost-effectiveness and his efficiency since it removes TN in the effluent. The UF membrane is used to further reduce COD\&TSS and also to reduce pathogens in the wastewater. The submerged configuration is being used and aerated which is a critical parameter in process performance since it is maintaining the solids in suspension, scrubs the membrane surface and delivers $\mathrm{O}_{2}$ to the biomass leading to a better biodegradability. The UV lights are added to the design to remove pathogens and disinfect the treated water.

\section{DISCUSSION}

\section{A. Pre-treatment Techniques of Poultry Slaughterhouse Wastewater}

The main purpose behind the primary treatment of PSW is to minimise the concentration of solids and coarse solids from the PSW and this minimisation of the solid content of PSW can contribute to the reduction of FOG as well as $\mathrm{BOD}_{5}$ due to the organic matter concentration of some entrapped solids such as feathers, blood flocs, meat trimmings and fats[6]. The most popular pre-treatment arrangement consists of screeners, settling tanks and flotation equalization for recuperating fats and proteins, the focus will be on screeners which will be described in the subsequent subsection. In this manner, huge solids with a radius/diameter of 10 to 30 millimetre $(\mathrm{mm})$ are held while the PSW goes through [29]. The screening procedure is the initial phase in wastewater treatment (WWT) forms as it expels huge or suspended solids (SS) and thick particles from the butchering procedure [29], [30].

\section{B. Anaerobic Digesters: Expanded Granular Sludge Bed Reactor}

Anaerobic reactors can be sorted by two fundamental criteria: first, regardless of whether the biomass is fixed to a surface, for example joined/prepared to help development or blend unreservedly with the digester fluid and secondly, by organic load rate (OLR), for example the influent mass level of COD required/unit volume[10].

EGSB reactor is the modification of the up-flow anaerobic sludge blanket reactor (UASB) through the introduction of the recycle. The increase of mixing is done by reusing a portion of effluent. The effluent which is reused implies bed's expansion and encourages a better contact of wastewater-biomass [31]. This digester is cost-effective, strong and progressively famous innovation since it works utilizing a fluidized bed, which permits expanding in carbon-based load and in cell maintenance, producing higher treatment efficiencies and sustainable power source [32]. All things considered; the productivity of this bioreactor fundamentally relies upon the conditions of operation. It shows qualities such as improved flow rate, dead zone with the free occurrence and shorter HRT [33], [34]

Operationability of the EGSB has increased in terms of performance over the years for the elimination of COD with a certain quantity of feed content for a certain HRT. Zhang[35] stated that EGSB removed up to $91 \%$ of COD for HRT of 2 days with OLR of $80 \mathrm{~g} \mathrm{sCOD} / \mathrm{L}$ while for the same reactor
Basitere[17] reported that COD removal was $55 \%$ with maximum OLR of 1gCOD/L.day for an HRT of 3 days and recently Williams[9] removed up to $93 \%$ tCOD at an HRT of 2.40days.

\section{Simultaneous Nitrification-Denitrification}

In the wastewater treatment plant, SND alludes to the elimination of absolute $\mathrm{NH}_{4}{ }^{+}-\mathrm{N}_{2}$, which happens through the tool of $\mathrm{O}_{2}$ consuming nitrifiers encouraged by denitrifying bacteria which are heterotrophic. The two procedure happens ideally at minimal temperatures and requires negligible breakdown oxygen concentrations taking into account one-step design of the removal of $\mathrm{TN}$, bringing about the reduction of operational expenses[10]. Few studies have reported using SND such as Rinquest [8] reported that TN removal was 33\% when operated in down-flow mode without aeration and $79 \%$ in up-flow mode with aeration. According to Williams [9] TN removal was found to be $85 \%$ and $57 \%$ during up-flow mode, optimum and average $\mathrm{NH}_{4}{ }^{+}-\mathrm{N}$ removal was found to be $87 \%$ and $58 \%$. DO concentration was maintained between 0.40 to $4.36 \mathrm{mg} / \mathrm{L}$ through the column with DO average being 1.38 $\mathrm{mg} / \mathrm{L}$.

\section{PSW Treatment using Ultrafiltration (UF) Membrane Processes}

The facilitation of removing SS, macromolecules and colloidal material is done by UF membrane processes. UF membrane has demonstrated to be proficient in removing particulate material, pathogens and environmental harmful nutrients from PSW [41].

\section{1) Different Configurations}

According to Wiesmann [42], there are three kinds of configurations membranes in membranes filtration of wastewaters: dead-end, submerged and crossflow configurations. But, the focus of this paper is on submerged configuration.

\section{2) Submerged Configuration}

Submerged configuration operates in quasi-steady state compare to dead-end, use less energy compared to crossflow, have low operating costs, the backwashing is done with and without air, minimization of build-up of a sludge cake layer. Recently, submerged configuration has turned out to be exceptionally critical in the field of aerobic biological wastewater treatment [42].

\section{E. Pathogens in PSW}

The process of slaughtering chicken/birds and cleaning of their facilities resulted in the generation of high organic matter, pollutants and pathogens inside the poultry wastewater which must be removed and disinfected from the wastewater so that PSW be discharged into the surroundings without causing any diseases or contamination. The focus in this section is the pathogens in the PSW. The pathogens in PSW are total coliform bacteria, Escherichia coli, enterococci, faecal coliforms, $E$. amnigenus, E. intermedius, E. aerogenes, Klebsiella sp., Citrobacter sp., Serratia sp., Proteus sp. Staphylococcus sp., Vibrio sp., Salmonella sp. which can be disinfected using UV lights [38], [39]. 


\section{F. The UV light in Wastewater Treatment}

The UV light is another sterilization technique for annihilating disease-causing bacteria in wastewater emanating in on-location wastewater treatment process. The UV light annihilates the hereditary material of bacteria which keeps them from reproducing. Wastewater must go through a progressed pre-treatment stage which is intended to expel the majority of organic matter and suspended solids before it goes through the UV sanitization unit. Wastewater streams parallel to the UV light in a slight film to build contact time. For the UV light to be successful, the UV radiation must come in direct contact with the microscopic organisms in the wastewater stream[39], [40].

UV radiation dosages have efficiently inactivated the pathogens (coliform organisms and Salmonella) in the study of performances of SBR, chemical-DAF and UV disinfection for PSW reclamation [4]. Also, According to Keller [14] sanitization by UV light has been accounted for as an appropriate innovation for the inactivation of pathogens (coliforms and Salmonella spp). Nasser [15] uncovered that the treated sewage sanitized by UV is reasonable for the unlimited water system of food crops and Dungeni [16] proposed UV sterilization as an extra treatment procedure of effluents to intensify the actual inactivation and evacuation of pathogenic microbes and germs.

\section{CONCLUSION}

In a study conducted by Basitere [17], the PSW system that was investigated included a joint EGSB-anoxic/aerobic tanks, which resulted in $65 \%$ total COD removal. However, the average efficiency of the EGSB reactor was $51 \%$ in terms of COD removal which this poor performance was due to high fats, oil\&grease (FOG) and suspended solids (SS) in the influent hence the importance of implementing a biological pre-treatment system [17]. Sheldon [11] conducted a study that investigated a combination of EGSB-MBR for the treatment of soft drink industrial wastewater, which resulted in a total COD removal of $95 \%$. According to Williams [9] the general system efficiency for combined EGSB-UF membrane in terms of total COD removal was $92 \%$ and TSS removal was $99 \%$ and for joint EGSB-SND-UF membrane was $92 \%$ for total COD removal and $99 \%$ for TSS removal in the treatment of PSW. Also, it has been reported by De Nardi [4] that UV radiation successfully inactivated the pathogens inside PSW and Keller [14] has stated that sanitization by UV light was an appropriate innovation for inactivating pathogens, follow by Dungeni [16] which proposed UV sterilization as an extra treatment procedure of effluents to intensify the actual inactivation and evacuation of pathogenic microbes and germs. Based on these studies, it is recommended that a treatment system consisting of a biophysico pre-treatment, an EGSB coupled with SND, submerged membrane and UV systems be investigated with regards to its capability of treating PSW.

\section{ACKNOWLEDGMENT}

All the authors would like to thank Cape Peninsula University of Technology (CPUT) and Bioresource Engineering Research Group (BIOERG) for funding towards the project and attendance at the conference.

\section{REFERENCES}

[1] Del Nery V, Pozzi E, Damianovic MHRZ, Domingues MR, Zaiat M. Granules characteristics in the vertical profile of a full-scale upflow anaerobic sludge blanket reactor treating poultry slaughterhouse wastewater. Bioresour Technol. 2008;99(6):2018-24. https://doi.org/10.1016/j.biortech.2007.03.019

[2] Avula RY, Nelson HM, Singh RK. Recycling of poultry process wastewater by ultrafiltration. Innov Food Sci Emerg Technol. 2009;10(1):1-8. https://doi.org/10.1016/j.ifset.2008.08.005

[3] Lo YM, Cao D, Argin-Soysal S, Wang J, Hahm TS. Recovery of protein from poultry processing wastewater using membrane ultrafiltration. Bioresour Technol. 2005;96(6):687-98. https://doi.org/10.1016/j.biortech.2004.06.026

[4] De Nardi IR, Del Nery V, Amorim AKB, dos Santos NG, Chimenes F. Performances of SBR, chemical-DAF and UV disinfection for poultry slaughterhouse wastewater reclamation. Desalination [Internet]. 2011;269(1-3):184-9. Available from: http://dx.doi.org/10.1016/j.desal.2010.10.060

[5] Basitere M. Performance Evaluation of an Up- and Down-Flow Anaerobic Reactor for The Treatment of Poultry Slaughterhouse Wastewater in South Africa. Cape Peninsula University of Technology; 2017.

[6] Bustillo-Lecompte C, Mehrvar M. Slaughterhouse Wastewater: Treatment, Management and Resource Recovery. Physico-Chemical Wastewater Treat Resour Recover. 2017;(May). https://doi.org/10.5772/65499

[7] Njoya M, Basitere M, Ntwampe SKO. High Rate Anaerobic Treatment of Poultry Slaughterhouse Wastewater (PSW). 2019. 38 p.

[8] Rinquest Z, Basitere M, Ntwampe SKO, Njoya M. Poultry slaughterhouse wastewater treatment using a static granular bed reactor coupled with single stage nitrification-denitrification and ultrafiltration systems. J Water Process Eng [Internet]. 2019;29(April 2018):100778. Available from: https://doi.org/10.1016/j.jwpe.2019.02.018

[9] Williams Y. Treatment of Poultry Slaughterhouse Wastewater Using An Expanded Granular Sludge Bed Anaerobic Digester Coupled with Anoxic/Aerobic Hybrid Side Stream Ultrafiltration Membrane Bioreactor. Cape Peninsula University of Technology; 2017.

[10] Gerardi MH. The Microbiology of Anaerobic Digesters. New Jersey: John Wiley\& Sons, Inc; 2003. 188 p. https://doi.org/10.1002/0471468967

[11] Sheldon MS, Erdogan IG. Multi-stage EGSB/MBR treatment of soft drink industry wastewater. Chem Eng J [Internet]. 2016; 285:368-77. Available from: http://dx.doi.org/10.1016/j.cej.2015.10.021

[12] De Jager D, Sheldon MS, Edwards W. Membrane bioreactor application within the treatment of high-strength textile effluent. Water Sci Technol. 2012;65(5):907-14. https://doi.org/10.2166/wst.2012.920

[13] Basitere M, Rinquest Z, Njoya M, Sheldon MS, Ntwampe SKO. Treatment of poultry slaughterhouse wastewater using a static granular bed reactor (SGBR) coupled with ultrafiltration (UF) membrane system. Water Sci Technol. 2017;76(1):106-14. https://doi.org/10.2166/wst.2017.179

[14] Keller R, Passamani F, Vaz L, Cassini ST, Gonçalves RF. Inactivation of Salmonella spp. from secondary and tertiary effluents by UV irradiation. Water Sci Technol. 2003;47(3):147-50. https://doi.org/10.2166/wst.2003.0186

[15] Nasser AM, Paulman H, Sela O, Ktaitzer T, Cikurel H, Zuckerman I, et al. UV disinfection of wastewater effluents for unrestricted irrigation. Water Sci Technol. 2006;54(3):83-8. https://doi.org/10.2166/wst.2006.452

[16] Dungeni M, van Der Merwe RR, Momba MNB. Abundance of pathogenic bacteria and viral indicators in chlorinated effluents produced by four wastewater treatment plants in the Gauteng Province, South Africa. Water SA. 2010;36(5):607-14. https://doi.org/10.4314/wsa.v36i5.61994

[17] Basitere M, Williams Y, Sheldon MS, Ntwampe SKO, De Jager D, Dlangamandla C. Performance of an expanded granular sludge bed (EGSB) reactor coupled with anoxic and aerobic bioreactors for treating 
poultry slaughterhouse wastewater. Water Pract Technol. 2016;11(1):86-92.

https://doi.org/10.2166/wpt.2016.013

[18] Pescod MB. Wastewater treatment and use in agriculture - FAO irrigation and drainage. Vol. 47, Food and Agriculture Organization of the United Nations Rome. 1992. 323 p.

[19] Rabah F. Physical, chemical and biological Characteristics of Wastewater. 2010;28 Available from: http://site.iugaza.edu.ps/halnajar/files/2010/02/unit-1.-Itroduction-to-wa stewater-treatment.pdf

[20] South African water act. National Water Act, Act No 36 of 1998. Water Resour. 1998;(36):94.

[21] Lapointe BE, Herren LW, Debortoli DD, Vogel MA. Evidence of sewage-driven eutrophication and harmful algal blooms in Florida's Indian River Lagoon. Harmful Algae [Internet]. 2015; 43:82-102. Available from: http://dx.doi.org/10.1016/j.hal.2015.01.004

[22] Khalid S, Shahid M, Natasha, Bibi I, Sarwar T, Shah AH, et al. A review of environmental contamination and health risk assessment of wastewater use for crop irrigation with a focus on low and high-income countries. Int J Environ Res Public Health. 2018;15(5):1-36. https://doi.org/10.3390/ijerph15050895

[23] Yetilmezsoy K, Sakar S. Improvement of COD and colour removal from UASB treated poultry manure wastewater using Fenton's oxidation. J Hazard Mater. 2008;151(2-3):547-58. https://doi.org/10.1016/j.jhazmat.2007.06.013

[24] Chávez P. C, Castillo L. R, Dendooven L, Escamilla-Silva EM. Poultry slaughter wastewater treatment with an up-flow anaerobic sludge blanket (UASB) reactor. Bioresour Technol. 2005;96(15):1730-6. https://doi.org/10.1016/j.biortech.2004.08.017

[25] Plumber HS, Kiepper BH, Ritz CW. Effects of broiler carcass bleed time and scald temperature on poultry processing wastewater. J Appl Poult Res. 2012;21(2):375-83. https://doi.org/10.3382/japr.2011-00444

[26] Rajakumar R, Meenambal T, Saravanan PM, Ananthanarayanan P. Treatment of poultry slaughterhouse wastewater in hybrid upflow anaerobic sludge blanket reactor packed with pleated polyvinyl chloride rings. Bioresour Technol [Internet]. 2012;103(1):116-22. Available from: http://dx.doi.org/10.1016/j.biortech.2011.10.030

[27] Bustillo-Lecompte C, Mehrvar M, Quiñones-Bolaños E. Slaughterhouse Wastewater Characterization and Treatment: An Economic and Public Health Necessity of the Meat Processing Industry in Ontario, Canada. J Geosci Environ Prot. 2016;04(04):175-86. https://doi.org/10.4236/gep.2016.44021

[28] Basitere M, Njoya M, Rinquest Z, Ntwampe SKO, Sheldon MS. Performance evaluation and kinetic parameter analysis for static granular bed reactor (SGBR) for treating poultry slaughterhouse wastewater at the mesophilic condition. Water Pract Technol. 2019;(June). https://doi.org/10.2166/wpt.2019.010

[29] Mittal GS. Treatment of wastewater from abattoirs before land application - a review. 2006; 97:1119-35. https://doi.org/10.1016/j.biortech.2004.11.02

[30] Templeton MR, Butler D. Introduction to Wastewater Treatment. Water Technology. 2010. 425-459 p. https://doi.org/10.1016/B978-1-85617-705-4.00014-9

[31] Bhattacharyya D, Singh KS. Understanding the Mixing Pattern in an Anaerobic Expanded Granular Sludge Bed Reactor: Effect of Liquid Recirculation. J Environ Eng. 2009;136(6):576-84. https://doi.org/10.1061/(ASCE)EE.1943-7870.0000187

[32] Cruz-Salomón A, Ríos-Valdovinos E, Pola-Albores F, Lagunas-Rivera S, Meza-Gordillo R, Ruíz-Valdiviezo VM, et al. Expanded granular sludge bed bioreactor in wastewater treatment ARTICLE INFO. Glob J Environ Sci Manag [Internet]. 2019;5(1):119-38. Available from: https://www.gjesm.net/

[33] Rajakumar R, Meenambal T, Banu JR, Yeom IT. Treatment of poultry slaughterhouse wastewater in upflow anaerobic filter under low upflow velocity. Int J Environ Sci Technol. 2011;8(1):149-58. https://doi.org/10.1007/BF03326204

[34] Evren M, Ozgun H, Kaan R, Ozturk I. Anaerobic Treatment of Industrial Effluents: An Overview of Applications. Waste Water - Treat Reutil. 2012;(June 2014).

https://doi.org/10.5772/16032
[35] Zhang Y, Yan L, Chi L, Long X, Mei Z, Zhang Z. Startup and operation of anaerobic EGSB reactor treating palm oil mill effluent. J Environ Sci. 2008;20(6):658-63. https://doi.org/10.1016/S1001-0742(08)62109-9

[36] Iorhemen OT, Hamza RA, Tay JH. Membrane bioreactor (Mbr) technology for wastewater treatment and reclamation: Membrane fouling. Membranes (Basel). 2016;6(2):13-6. https://doi.org/10.3390/membranes6020033

[37] Abdel Kader AM. a Review of Membrane Bioreactor (Mbr) Technology and Their Applications in the Wastewater Treatment Systems. Desalin Water Treat. 2015;32(March 2007):111-9.

[38] Barros LSS, Amaral LA, Lorenzon CS, Junior JL, Neto JGM. Potential microbiological contamination of effluents in poultry and swine abattoirs. Epidemiol Infect. 2007;135(3):505-18 https://doi.org/10.1017/S0950268806006972

[39] Al-Gheethi AA, Efaq AN, Bala JD, Norli I, Abdel-Monem MO, Ab. Kadir MO. Removal of pathogenic bacteria from sewage-treated effluent and biosolids for agricultural purposes. Appl Water Sci [Internet]. 2018;8(2):1-25. Available from: https://doi.org/10.1007/s13201-018-0698-6

[40] Nyserda. Evaluation of Ultraviolet (UV) Technologies for Wastewater Treatment Plant Effluent. Albany, NY; 2004.

[41] Yordanov D. Preliminary study of the efficiency of ultrafiltration treatment of poultry slaughterhouse wastewater. Bulg J Agric Sci. 2010;16(6):700-4.

[42] Wiesmann U, Choi IS, Dombrowski E. Fundamentals of Biological Wastewater Treatment Fundamentals. 2007. https://doi.org/10.1002/9783527609604

[43] Kaskote E. Primary treatment, Secondary treatment and Tertiary treatment. 2019;2

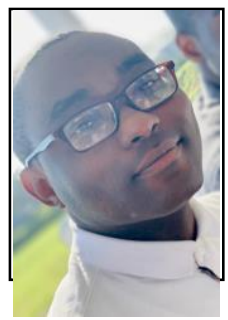

H. MEYO was born in Gabon and raised in Libreville, Estuary Province in Gabon on March 10, 1988. Meyo obtained his national diploma in chemical engineering in 2015 , the B-Tech degree in Chemical engineering in 2017 and his project management certificate in 2018 all at the Cape Peninsula University of Technology, South Africa. He is currently undergoing his master's degree at the same institution. 